\title{
Selectivity of Glyphosate TaNk Mixtures for RR Soybean ${ }^{1}$
}

\author{
Seletividade de Glyphosate em Misturas em Tanque para Soja RR
}

\author{
ALONSO, D.G. ${ }^{2}$, CONSTANTIN, J. ${ }^{3}$, OLIVEIRA JR., R.S. ${ }^{3}$, ARANTES, J.G.Z. ${ }^{2}$, CAVALIERI, S.D. ${ }^{4}$, \\ SANTOS, G. ${ }^{5}$, RIOS, F.A. ${ }^{5}$ and FRANCHINI, L.H.M. ${ }^{5}$
}

\begin{abstract}
An active ingredients mixture of different action mechanisms is an essential tool to prevent or manage areas with resistant weeds. However, it is important that such a mixture provides adequate selectivity to the crop. The aim of this work was to evaluate glyphosate selectivity to glyphosate-resistant (RR) soybean, and also verify if there is selectivity in mixtures with other active ingredients applied postemergence aimed at new control strategies, which might be used in $R R$ soybean cultivation. The herbicides and respective rates ( $\left.g \mathrm{ha}^{-1}\right)$ evaluated were: glyphosate (720, $960,1,200$, and 1,440), and the mixtures of glyphosate (960) with cloransulam-methyl (30.24), fomesafen (125), lactofen (72), chlorimuron-ethyl (12.5), flumiclorac-pentyl (30), bentazon (480), or imazethapyr (80). All treatments were applied in postemergence when the soybean crop was at V2 to V3 stage. Treatments with glyphosate or in mixtures with postemergent herbicides showed visual effects of phytotoxicity when applied to the glyphosate-resistant soybean. Effects such as reduction in plant height, crop closure, number of pods per plant, and hundred grain weight could be observed. However, the effects related to plant development were mostly transient and did not persist during the crop cycle. Among the studied treatments, only the mixture of glyphosate and lactofen was not selective to the crop, promoting negative effects on most characteristics analyzed and consequently reducing grain yield.
\end{abstract}

Keywords: herbicides, glyphosate-resistant soybean, tolerance, injury.

\begin{abstract}
RESUMO - A mistura de ingredientes ativos de diferentes mecanismos de ação é uma ferramenta essencial para prevenir ou manejar áreas com plantas daninhas resistentes. No entanto é importante que tais associações forneçam adequada seletividade para a cultura. $\mathrm{O}$ objetivo deste trabalho foi avaliar a seletividade do glyphosate a soja RR, e verificar também, se existe seletividade a misturas com outros ingredientes ativos, aplicados em pósemergência, visando novas estratégias de controle que poderão ser empregadas no cultivo da soja RR. Os herbicidas e respectivas doses ( $\mathrm{g} \mathrm{ha}^{-1}$ ) avaliadas foram: glyphosate isolado (720, 960, 1.200 e 1.440) e as misturas de glyphosate (960) com cloransulam-methyl (30,24), fomesafen (125), lactofen (72), chlorimuron-ethyl $(12,5)$, flumiclorac-pentyl (30), bentazon (480) e imazethapyr (80). Todos os tratamentos foram aplicados em dose única em pósemergência quando a soja estava no estádio V2 a V3. Tratamentos com glyphosate isolado ou em mistura com herbicidas pós-emergentes aplicados em dose única promoveram efeitos visuais de fitointoxicação quando aplicados na soja resistente ao glyphosate. Efeitos como redução na altura das plantas, no fechamento da cultura, no número de vagens por planta e na massa de cem grãos puderam ser observados. Entretanto, os efeitos relatados ao desenvolvimento das plantas foram na sua maioria transientes, não persistindo durante todo ciclo da cultura. Dentre os tratamentos estudados, somente a mistura entre glyphosate e lactofen não apresentou seletividade à cultura, promovendo efeitos negativos na maioria das características estudadas e consequentemente reduzindo a produtividade de grãos.
\end{abstract}

Palavras-chaves: herbicidas, soja resistente ao glyphosate, tolerância, injuria.

1 Recebido para publicação em 8.9.2010 e aprovado em 10.3.2011.

2 Doutorando do Programa de Pós-Graduação em Agronomia, Bolsista do CNPq - Brasil, Núcleo de Estudos Avançados em Ciência das Plantas Daninhas, Universidade Estadual de Maringá - NAPD/UEM, Av. Colombo 5790, 87020-900 Maringá-PR, <alonsodg07@hotmail.com>; ${ }^{3}$ Professor, Doutor Associado, Dep. de Agronomia, NAPD/UEM; ${ }^{4}$ Engo-Agr ${ }^{\circ}$., D. Sc., Pesquisador da Embrapa Hortaliças. Rod. BR 060, Km 9 Brasília/Anápolis, 70359-970 Brasília-DF; ; ${ }^{5}$ Mestrando do Programa de Pós-Graduação em Agronomia, NAPD/UEM.

Planta Daninha, Viçosa-MG, v. 29, n. 4, p. 929-937, 2011 


\section{INTRODUCTION}

Soybean crop has been characterized by intense technological developments in recent years. However, its coexistence with weeds still demands research efforts, since weeds are one of the main causes of yield reduction. According to Lamego et al. (2004), the effects of weed interference on cultivated plants might compromise the development of reproductive structures and affect the components of grain yield.

The cultivation of transgenic glyphosateresistant (RR) soybean has promoted a considerable increase in the use of glyphosate to control weeds. Although glyphosate provides efficient control for most weeds, its intense use has led to a continuous selection of weeds that are difficult to control. There are reports of weeds that are tolerant or resistant to glyphosate in several important soybean production areas (Lich et al., 1997; Norris et al., 2001; Norsworthy et al., 2001, 2002).

In agricultural areas in the Brazilian savanna, tolerant weed species such as Synedrellopsis grisebachii, Spermacoce latifolia, Commelina benghalensis and Tridax procumbens have been selected resulting from successive glyphosate applications (Procópio et al., 2007). In addition, five cases of glyphosate-resistant weeds have been reported in Brazil: Lolium multiflorum, Conyza bonariensis, Conyza canadensis, Euphorbia heterophylla and Digitaria insularis. In 2006, the first case of multiple resistance involving glyphosate was registered after the identification of glyphosate-resistant Euphorbia heterophylla biotypes, which were also resistant to ALS inhibitors (Weed Science, 2009).

One of the options to reduce selection pressure for the development of glyphosate resistance is the use of mixtures of herbicides with different mechanisms of actions (Lich et al., 1997). According to these authors, glyphosate tank mixtures with low rates of selective herbicides might potentially result in an economic program of wide spectrum weed control with postemergence herbicides. Moreover, the combination of glyphosate with selective herbicides with residual activity in soil can prevent the emergence of late fluxes of weeds during the crop cycle.
Herbicide combinations are also beneficial as they require less time for application and cost less compared to the single application of each herbicide (Norris et al., 2001). These combinations might also increase the spectrum of weeds controlled. However, herbicide mixtures can increase crop injury, even when each herbicide applied alone is considered selective to the crop. Glyphosate applications have resulted in significant injuries when applied at certain conditions or with certain formulations of glyphosate salt (Reddy \& Zablotowicz, 2003; Zobiole at al., 2009; Oliveira Jr. et al., 2008). In contrast, Correia $\&$ Durigan (2007) tested several commercial glyphosate formulations in Brazil and did not observe significant symptoms of herbicide intoxication on soybean plants, cultivars CD 214 RR and M-SOY 8008 RR. Mixtures of glyphosate with diclosulam, clorosulammethyl, flumioxazin and S-metolachlor did not affect soybean crop grain yield (NETO et al., 2009). However, plant growth and canopy were affected by glyphosate mixtures with flumioxazin or with S-metolachlor.

As research results do not seem to be satisfactorily conclusive with regard to selectivity of mixtures with glyphosate for RR soybean, this work was aimed at evaluating the selectivity of glyphosate alone, or in mixtures with other herbicides, in relation to crop development and grain yield of $R R$ soybean.

\section{MATERIAL AND METHODS}

The experiment was carried out on a no-tillage area at Nossa Senhora Aparecida

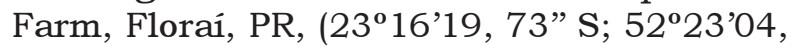
30 " $\mathrm{W}$; altitude $=443 \mathrm{~m})$. Local climate is characterized as subtropical with summer showers and dry winter - or Cfa, according to Wilhelm Köeppen's classification. The soil of the experimental area was identified as Rhodic Ferralsol with sandy texture, constituted of $36 \%$ coarse sand, $54 \%$ fine sand, $8 \%$ clay, and $2 \%$ silt. Chemical analysis carried out in soil samples taken from 0 to $20 \mathrm{~cm}$ depth, showed $\mathrm{pH} 5,7$ in $\mathrm{CaCl}_{2}, 2.36 \mathrm{cmol}_{\mathrm{c}} \mathrm{dm}^{-3}$ $\mathrm{H}^{+}+\mathrm{Al}^{3+} ; 2,18 \mathrm{cmol}_{\mathrm{c}} \mathrm{dm}^{-3} \mathrm{Ca}^{+2} ; 0,36 \mathrm{cmol}_{\mathrm{c}} \mathrm{dm}^{-3}$ $\mathrm{Mg}^{+2} ; 0,13 \mathrm{cmol}_{\mathrm{c}} \mathrm{dm}^{-3} \mathrm{~K}^{+} ; 15,0 \mathrm{mg} \mathrm{dm}^{-3} \mathrm{P}$, and $4,35 \mathrm{~g} \mathrm{dm}^{-3} \mathrm{C}$. 
The site had been cultivated with oats in the winter prior to soybean sowing. Oat biomass was burned down 10 days before soybean sowing with $1.260 \mathrm{~g} \mathrm{ha}^{-1}$ glyphosate. Fertilization consisted of $270 \mathrm{~kg} \mathrm{ha}^{-1}$ of the 0-18-18 NPK formula and $83 \mathrm{~kg} \mathrm{ha}^{-1}$ of potassium chloride. Seeds were treated with fungicides $\left(35 \mathrm{~g} \mathrm{~kg}^{-1}\right.$ Fludioxonil $+10 \mathrm{~g} \mathrm{~kg}^{-1}$ of Metalaxyl-M) at $0,001 \mathrm{~L} \mathrm{~kg}^{-1}$ of seeds and with insecticide (250 $\mathrm{g} \mathrm{L}^{-1}$ Fipronil) at $0,001 \mathrm{~L} \mathrm{~kg}^{-1}$ of seeds, and also with peat inoculant at the rate $2 \mathrm{~g} \mathrm{~kg}^{-1}$ of seeds. Forty days after germination, $83 \mathrm{~kg} \mathrm{ha}^{-1}$ of potassium chloride was applied. Sowing was carried on 11/9/2006 with $0,45 \mathrm{~m}$ between rows and density of approximately 18 seeds $\mathrm{m}^{-1}$. The cultivar used in the experiment was CD $214 \mathrm{RR}$, an early maturation group cultivar. Harvest was done manually on 3/20/2007.

The experimental design was completely randomized in split-plot scheme with two checks, and four replicates. The herbicides were the main factor studied in the plots, and herbicide presence or absence was studied in the subplots. For each applied rate, a no spray check was left side by side the applied plot, with the intent of providing a site-specific correction when data were submitted to covariance analysis. Similar technique was previously used by Fagliari et al. (2001) for the evaluation of herbicide selectivity in sugarcane. More recently, it has also been used to study herbicide selectivity in soybeans (Meschede et al., 2004; Jaremtchuk et al., 2008). According to Meschede et al. (2004), this type of experiment brings more efficient local control, especially when compared to the traditional randomized blocks design with a single check per block.

The subplots consisted of eight rows of sowing $0,45 \mathrm{~m}$ apart and five meters long totalizing $18 \mathrm{~m}^{2}$ per subplot. The subplot area used for evaluations was made up of six rows, disregarding the first and final half meter of each subplot. To prevent weed interference on soybeans, all subplots were kept free of weeds by manual hoeing throughout crop cycle.

Treatments (rates at $\mathrm{g} \mathrm{ha}^{-1}$ ) evaluated were: glyphosate alone at 720, 960, 1,200 and 1,440 , and glyphosate (960) mixtures with cloransulam-methyl (30.24), fomesafen
(125), lactofen (72), chlorimuron-ethyl (12.5), flumiclorac-pentyl (30), bentazon (480), and imazethapyr (80), at a single application in postemergence when the crop was at the V2 to V3 stage.

A backpack sprayer operating under constant pressure $\left(2,0 \mathrm{kgf} \mathrm{cm}^{-2}\right)$ and equipped with XR-110.02 flat fan nozzles, provide $200 \mathrm{~L} \mathrm{ha}^{-1}$ of spray volume. Conditions at spraying were temperature $31^{\circ} \mathrm{C}$ and relative humidity $62 \%$, with wet soil and $2 \mathrm{~km} \mathrm{~h}^{-1}$ wind speed.

Visual evaluations of phytotoxicity, plant height, stand, and soil cover by crop canopy were conducted, and the number of pods per plant was counted. After harvest, the hundred grain mass and yield were evaluated.

For the visual phytotoxicity evaluations, percentage marks were attributed to each experimental unit sprayed with herbicides (visual scale, $0-100 \%$ ) considering, in this case, visual symptoms on plants according to its development (SBCPD, 1995) at 3, 7, and 15 days after application (DAA). Visual evaluations of soil cover by crop canopy were carried out at 3,7 , and 15 DAA to determine the effect of treatments on the development of plant leaf area. The scale used was from zero (no soil cover between crop lines) to 100\% representing the complete soil cover by the crop.

The number of live plants was counted at 15 DAA in three linear meters in two central rows of each subplot, and results were expressed as plants $\mathrm{m}^{-1}$. To determine the average height, the height of 10 plants per subplot was measured. Plants were measured randomly inside the subplot area of each experimental subplot. The measurement was carried out from the soil surface to the insertion of the last trifoliolate leaves completely expanded at 15 and 90 DAA.

During harvest, pods were counted in ten plants per plot that were taken randomly from the subplot area. Subplot area of each experimental unit was harvested manually, packed, and weighed. The hundred grain mass was obtained by counting and weighing three samples of one hundred grains per experimental subplot. Three samples were 
taken per subplot to determine grain moisture. Data were corrected to $13 \%$ moisture.

Data were submitted to variance analysis by $F$ test and the averages were compared by Tukey test at $5 \%$ probability.

\section{RESULTS AND DISCUSSION}

\section{Crop injury}

All treatments caused injuries to soybean plants leading to the appearance of visual phytotoxicity symptoms of variable intensity for each treatment (Table 1). However, phytotoxicity effects observed during crop cycle were mostly transitory with varying persistence. Toxicity symptom recovery from herbicide treatments containing glyphosate in glyphosate-resistant soybean has been reported by several authors such as Lich et al. (1997), Gonzini et al. (1999), Elmore et al. (2001), Grey \& Raymer (2002), Ellis \& Griffin (2003), Norsworthy (2004), and Procópio et al. (2007).

The mixtures caused a higher level of injuries at 3 DAA than any rate of glyphosate alone. In contrast, visible symptom intensity at 7 DAA started to decrease in treatments with mixtures whereas intensity increased for treatments with glyphosate alone. Evaluations of results of phytotoxicity after 7 DAA are not

Table 1 - Average soybean injury (visual scale, \%), cultivar CD $214 \mathrm{RR}$, submitted to different treatments with glyphosate isolated or in mixture with other herbicides in postemergence. Floraí, PR, 2006/2007

\begin{tabular}{|l|c|c|c|}
\hline \multirow{2}{*}{ Herbicide } & \multirow{2}{*}{$\begin{array}{c}\text { Rate } \\
\left(\mathrm{g} \mathrm{ha}^{-1}\right)\end{array}$} & \multicolumn{2}{c|}{ Soybean injury (\%) } \\
\cline { 3 - 4 } & & \multicolumn{2}{|c|}{ Evaluation periods } \\
\cline { 3 - 4 } & & DAA & 7 DAA \\
\hline Glyphosate+cloransulam-methyl & $960+30.24$ & 38,8 & 31.3 \\
\hline Glyphosate+fomesafen & $960+125$ & 58.8 & 51.5 \\
\hline Glyphosate+lactofen & $960+72$ & 73.3 & 65.0 \\
\hline Glyphosate+chlorimuron-ethyl & $960+12.5$ & 59.5 & 56.3 \\
\hline Glyphosate+flumiclorac-pentyl & $960+30$ & 38.0 & 37.5 \\
\hline Glyphosate+bentazon & $960+480$ & 28.3 & 34.5 \\
\hline Glyphosate+imazethapyr & $960+80$ & 51.3 & 40.8 \\
\hline Glyphosate & 720 & 17.0 & 27.0 \\
\hline Glyphosate & 960 & 23.3 & 30.0 \\
\hline Glyphosate & 1,200 & 23.8 & 32.5 \\
\hline Glyphosate & 1,440 & 21.3 & 32.5 \\
\hline
\end{tabular}

$(\%): 0 \%=$ no injuries, $100 \%=$ plant death. $+:$ Herbicides mixtures shown because none of the treatments resulted in visible symptoms in young leaves. Although mixtures had a higher initial impact, phytotoxicity effects tended to be equal to glyphosate alone from 15 DAA on (data not shown).

Plants treated with glyphosate+ cloransulam-methyl showed symptoms of mosaic internerval chlorosis and generalized leaflet distortion (Figure 1A). For glyphosate+ fomesafen, visible symptoms in the plants were chlorotic stains, progressing to necrosis and generalized distortion of leaflets which were in contact with the herbicide spray (Figures 1B). The glyphosate+lactofen mixture caused severe visual injuries, showing similar symptoms to those observed in the glyphosate+ fomesafen treatment, although with greater intensity (Figures 1C). Plants treated with glyphosate+chlorimuron-ethyl showed necrosis progressing from outer to center of the blade of some leaflets, and generalized chlorosis and leaf distortion (Figure 1D). With regards to the glyphosate+flumiclorac-pentyl mixture, the observed symptoms were similar to those reported for the mixtures containing other PROTOX inhibitors, lactofen, and fomesafen. However, injuries were less intense in relation to these mixtures (Figure 1E). Fausey \& Renner (2001) had previously showed that applications of the glyphosate $\left(850 \mathrm{~g} \mathrm{ha}^{-1}\right)$ in tank mixture with flumiclorac-pentyl $\left(30 \mathrm{~g} \mathrm{ha}^{-1}\right)$ caused the appearance of necrotic points in $11 \%$ of the leaves evaluated 7 DAA. Nevertheless, the authors reported that the injuries were transient, and were no longer present in the evaluation at 21 DAA.

The glyphosate+bentazon mixture also caused chlorotic stains with progression to necrosis and light leaflet distortion (Figure 1F). For plants treated with glyphosate+ imazethapyr as well as the other mixtures with PROTOX inhibitors, internerval chlorosis and generalized leaf distortion were observed (Figure 1G).

In all treatments with glyphosate alone, symptoms such as chlorosis and leaf distortion in younger leaflets were noticed (Figure 1H). This is in contrast to Fausey \& Renner (2001) who reported that glyphosate applications $\left(850 \mathrm{~g} \mathrm{ha}^{-1}\right)$ to the soybean plant at the two to three trifoliolate leaves stage did not cause 

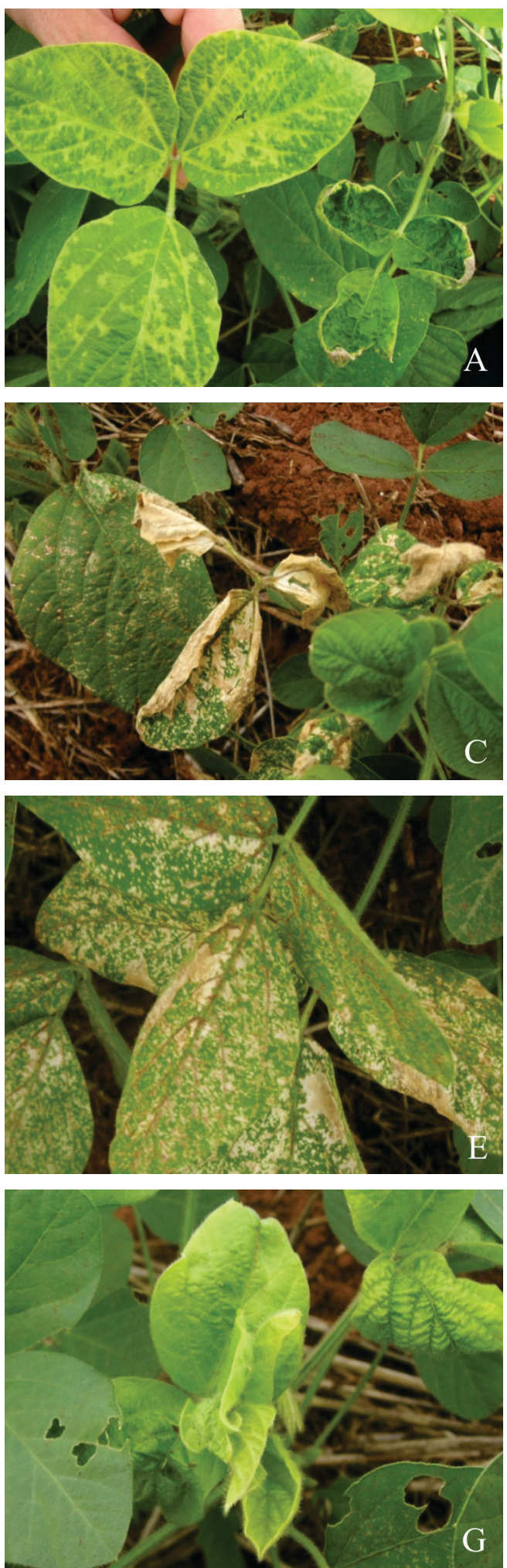
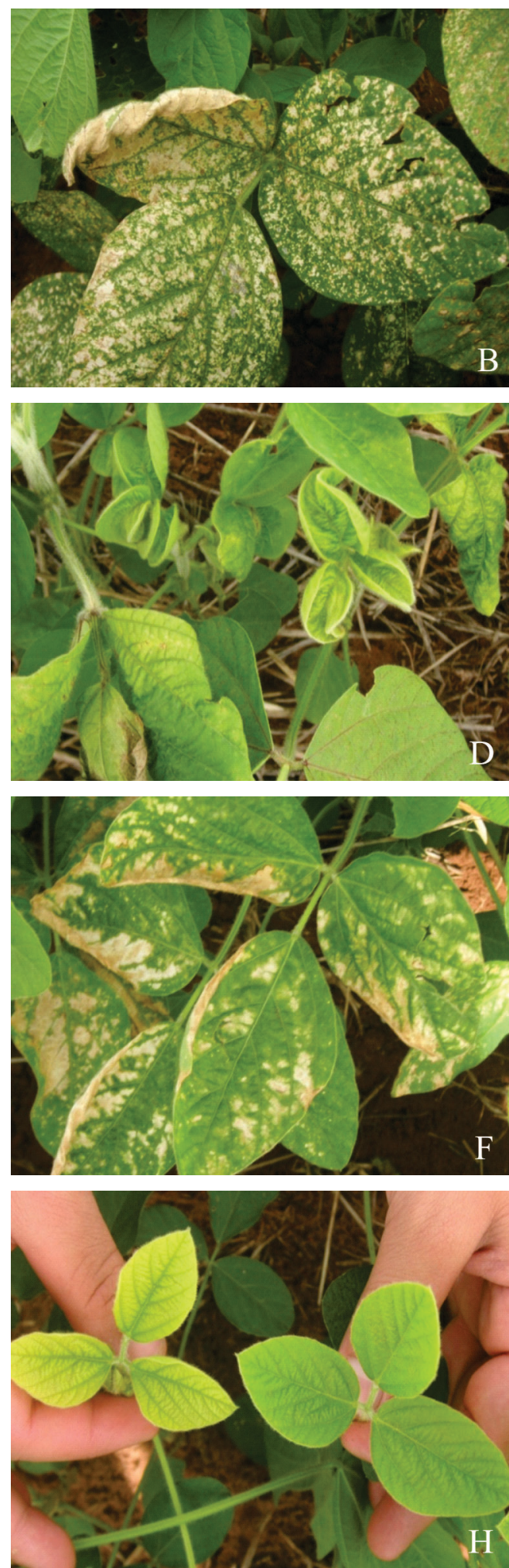

Figure 1 - Injuries caused by the application of glyphosate+cloransulam-methyl (960+30.24) (A); glyphosate+fomesafen $(960+125)$ (B); glyphosate+lactofen (960+72) (C); glyphosate+chlorimuron-ethyl (960+12.5) (D); glyphosate+flumiclorac-pentyl $(960+30)(\mathrm{E})$; glyphosate+bentazon $(960+80)(\mathrm{F})$; glyphosate+imazethapyr $(960+80)$ $(\mathrm{G})$; glyphosate (1200) (H), at 3 DAA. 
visual injuries on the plants. Correia \& Durigan (2007) compared several commercial formulations of glyphosate and concluded that the herbicides did not cause visible phytotoxic effects in CD 214 RR soybean plants. Procópio et al. (2007) also reported that toxic symptoms in RR soybean plants caused by application of glyphosate alone were not observed. Visual injuries observed in soybean plants in this study after glyphosate application have been associated with the effects of such herbicides on the contents of macro and micronutrients and on the photosynthetic rate and chlorophyll content (Zobiole et al., 2009).

\section{Visual evaluation of soil cover by crop canopy}

Treatments with glyphosate $(720$ and 1,200 $\mathrm{g} \mathrm{ha}^{-1}$ ) and the mixture with bentazon did not significantly affect the crop canopy development at all evaluation periods (Table 2). In contrast, treatments with glyphosate $\left(1,440 \mathrm{~g} \mathrm{ha}^{-1}\right)$ and the mixtures of glyphosate with cloransulam-methyl and fomesafen provided soil cover inferior to their respective checks at 3 and 7 DAA. Glyphosate $\left(960 \mathrm{~g} \mathrm{ha}^{-1}\right)$ and its mixture with flumiclorac-pentyl presented reduction in soil cover only at 7 DAA.
However, these treatments did not differ statistically from checks at 15 DAA suggesting that the canopy development recovered rapidly.

Treatments containing lactofen, chlorimuron-ethyl, and imazethapyr in mixtures with glyphosate, were compared to their respective checks and affected the vegetative development of plants at the three evaluations, suggesting that injuries lasted longer in these cases, which is in agreement with visual injuries observations. It is possible that such effects might be associated with some residual activity of imazethapyr and chlorimuron present in the soil, which may have contributed to the extension of their effects on soybean growth. Considering lactofen, the most prolonged effect on closure is undoubtedly related to the level of injury the mixture caused to the soybean leaf area, which was the highest among treatments at 7 DAA (Table 1).

\section{Plant height and stand}

Average heights of soybean plants are presented in Table 3. Glyphosate alone, when applied at $1.440 \mathrm{~g} \mathrm{ha}^{-1}$ was harmful to soybean

Table 2 - Soil cover by soybean canopy (visual, \%) cultivar CD 214 RR, submitted to different treatments with glyphosate isolated or in mixtures with other herbicides in postemergence, at 3, 7, and 15 days after application (DAA). Floraí, PR, $2006 / 2007$

\begin{tabular}{|c|c|c|c|c|c|c|c|}
\hline \multirow{3}{*}{ Herbicide } & \multirow{3}{*}{$\begin{array}{l}\text { Rate } \\
\left(\mathrm{g} \mathrm{ha}^{-1}\right)\end{array}$} & \multirow{2}{*}{\multicolumn{2}{|c|}{$\frac{\% \text { of soil cover (3 DAA) }}{\text { Herbicide }^{1 /}}$}} & \multirow{2}{*}{\multicolumn{2}{|c|}{$\frac{\% \text { of soil cover (7 DAA) }}{\text { Herbicide }^{1 /}}$}} & \multirow{2}{*}{\multicolumn{2}{|c|}{$\frac{\% \text { of soil cover (15 DAA) }}{\text { Herbicide }^{1 /}}$}} \\
\hline & & & & & & & \\
\hline & & With & Without & With & Without & With & Without \\
\hline Glyphosate+cloransulam-methyl & $960+30.24$ & $52.50 \mathrm{~b}$ & $60.00 \mathrm{a}$ & $48.25 \mathrm{~b}$ & $55.75 \mathrm{a}$ & $97.50 \mathrm{a}$ & $97.75 \mathrm{a}$ \\
\hline Glyphosate+fomesafen & $960+125$ & $42.00 \mathrm{~b}$ & $57.75 \mathrm{a}$ & $43.25 \mathrm{~b}$ & $54.88 \mathrm{a}$ & $97.00 \mathrm{a}$ & $97.75 \mathrm{a}$ \\
\hline Glyphosate+lactofen & $960+72$ & $31.25 \mathrm{~b}$ & $49.25 \mathrm{a}$ & $35.75 \mathrm{~b}$ & $51.00 \mathrm{a}$ & $95.50 \mathrm{~b}$ & $96.75 \mathrm{a}$ \\
\hline Glyphosate+chlorimuron-ethyl & $960+12.5$ & $36.25 \mathrm{~b}$ & $52.25 \mathrm{a}$ & $37.00 \mathrm{~b}$ & $50.13 \mathrm{a}$ & $95.00 \mathrm{~b}$ & $96.63 \mathrm{a}$ \\
\hline Glyphosate+flumiclorac-pentyl & $960+30$ & $46.25 \mathrm{a}$ & $50.50 \mathrm{a}$ & $46.25 \mathrm{~b}$ & $52.00 \mathrm{a}$ & $96.75 \mathrm{a}$ & $97.00 \mathrm{a}$ \\
\hline Glyphosate+bentazon & $960+480$ & $53.75 \mathrm{a}$ & $58.63 \mathrm{a}$ & $47.50 \mathrm{a}$ & $52.00 \mathrm{a}$ & $97.00 \mathrm{a}$ & $97.00 \mathrm{a}$ \\
\hline Glyphosate+imazethapyr & $960+80$ & $37.50 \mathrm{~b}$ & $55.50 \mathrm{a}$ & $40.00 \mathrm{~b}$ & $52.00 \mathrm{a}$ & $94.75 \mathrm{~b}$ & $97.13 \mathrm{a}$ \\
\hline Glyphosate & 720 & $50.75 \mathrm{a}$ & $54.25 \mathrm{a}$ & $47.50 \mathrm{a}$ & $50.38 \mathrm{a}$ & $97.75 \mathrm{a}$ & $96.50 \mathrm{~b}$ \\
\hline Glyphosate & 960 & $57.50 \mathrm{a}$ & $56.50 \mathrm{a}$ & $45.25 \mathrm{~b}$ & $52.63 \mathrm{a}$ & $97.25 \mathrm{a}$ & $97.25 \mathrm{a}$ \\
\hline Glyphosate & 1,200 & $56.00 \mathrm{a}$ & $56.13 \mathrm{a}$ & $48.25 \mathrm{a}$ & $49.50 \mathrm{a}$ & $97.75 \mathrm{a}$ & $96.63 \mathrm{a}$ \\
\hline Glyphosate & 1,440 & $46.25 \mathrm{~b}$ & $55.00 \mathrm{a}$ & $41.25 \mathrm{~b}$ & $48.50 \mathrm{a}$ & $96.25 \mathrm{a}$ & $96.63 \mathrm{a}$ \\
\hline \multicolumn{2}{|l|}{ CV $(\%)$} & \multicolumn{2}{|c|}{9.68} & \multicolumn{2}{|c|}{7.89} & \multicolumn{2}{|c|}{0.86} \\
\hline \multicolumn{2}{|c|}{ L.S.D. (Tukey, 5\%) } & \multicolumn{2}{|c|}{7.07} & \multicolumn{2}{|c|}{5.42} & \multicolumn{2}{|c|}{1.20} \\
\hline
\end{tabular}

For each variable analyzed, means followed by the same letters in the same line (with $\mathrm{x}$ without herbicide) do not differ from each other by Tukey test at $5 \%$ probability. ${ }^{1 /}$ Represents treatments which received herbicide application (WITH) and their respective twofold checks which did not receive herbicide treatments. +: Herbicides mixtures. 
Table 3 - Average height (cm) at 15 and 90 days after application (DAA) CD 214 RR cultivar, submitted to different treatments with glyphosate isolated or in mixture with other herbicides in postemergence. Floraí, PR, 2006/2007

\begin{tabular}{|c|c|c|c|c|c|}
\hline \multirow{3}{*}{ Herbicide } & \multirow{3}{*}{$\begin{array}{l}\text { Rate } \\
\left(\mathrm{g} \mathrm{ha}^{-1}\right)\end{array}$} & \multirow{2}{*}{\multicolumn{2}{|c|}{$\begin{array}{c}\text { Height (15 DAA) } \\
\text { Herbicide }^{\underline{1}}\end{array}$}} & \multirow{2}{*}{\multicolumn{2}{|c|}{$\begin{array}{c}\text { Height (90 DAA) } \\
\text { Herbicide }^{\underline{1}}\end{array}$}} \\
\hline & & & & & \\
\hline & & With & Without & With & Without \\
\hline Glyphosate+cloransulam-methyl & $960+30.24$ & $37.78 \mathrm{a}$ & $37.88 \mathrm{a}$ & $50.10 \mathrm{a}$ & $52.78 \mathrm{a}$ \\
\hline Glyphosate+fomesafen & $960+125$ & $32.35 \mathrm{~b}$ & $37.64 \mathrm{a}$ & $43.85 \mathrm{~b}$ & $54.26 \mathrm{a}$ \\
\hline Glyphosate+lactofen & $960+72$ & $31.30 \mathrm{a}$ & $33.19 \mathrm{a}$ & $43.75 \mathrm{~b}$ & $50.05 \mathrm{a}$ \\
\hline Glyphosate+chlorimuron-ethyl & $960+12.5$ & $31.40 \mathrm{~b}$ & $35.74 \mathrm{a}$ & $51.60 \mathrm{a}$ & $52.41 \mathrm{a}$ \\
\hline Glyphosate+flumiclorac-pentyl & $960+30$ & $33.70 \mathrm{a}$ & $34.70 \mathrm{a}$ & $45.05 \mathrm{a}$ & $47.99 \mathrm{a}$ \\
\hline Glyphosate+bentazon & $960+480$ & $34.63 \mathrm{a}$ & $37.66 \mathrm{a}$ & $45.08 \mathrm{~b}$ & $51.14 \mathrm{a}$ \\
\hline Glyphosate+imazethapyr & $960+80$ & $32.33 \mathrm{~b}$ & $36.51 \mathrm{a}$ & $43.70 \mathrm{~b}$ & $49.51 \mathrm{a}$ \\
\hline Glyphosate & 720 & $33.33 \mathrm{a}$ & $35.29 \mathrm{a}$ & $50.83 \mathrm{a}$ & $50.79 \mathrm{a}$ \\
\hline Glyphosate & 960 & $37.45 \mathrm{a}$ & $35.56 \mathrm{a}$ & $48.00 \mathrm{a}$ & $50.13 \mathrm{a}$ \\
\hline Glyphosate & 1200 & $35.93 \mathrm{a}$ & $37.26 \mathrm{a}$ & $52.70 \mathrm{a}$ & $51.16 \mathrm{a}$ \\
\hline Glyphosate & 1440 & $33.78 \mathrm{a}$ & $34.74 \mathrm{a}$ & $43.90 \mathrm{~b}$ & $49.99 \mathrm{a}$ \\
\hline \multicolumn{2}{|l|}{$\mathrm{CV}(\%)$} & \multicolumn{2}{|c|}{7.92} & \multicolumn{2}{|c|}{7.40} \\
\hline \multicolumn{2}{|c|}{ L.S.D. (Tukey, $5 \%$ ) } & \multicolumn{2}{|c|}{3.99} & \multicolumn{2}{|c|}{5.23} \\
\hline
\end{tabular}

For each variable analyzed, means followed by the same letters in the same line (with $\mathrm{x}$ without herbicide) do not differ from each other by Tukey test at $5 \%$ probability. ${ }^{1 /}$ Represents treatments which received herbicide application (WITH) and their respective twofold checks which did not receive herbicide treatments. +: Herbicides mixtures.

growth at 90 DAA evaluation. With regard to mixtures, those containing lactofen, chlorimuron, and bentazon also affected plant height in at least one of the evaluations. In contrast, glyphosate mixtures with fomesafen and imazethapyr affected plant height more consistently at both 15 and 90 DAA. Ellis \& Griffin (2003) observed that treatments with glyphosate ( 840 and $1,120 \mathrm{~g} \mathrm{ha}^{-1}$ ), alone or in mixtures, with reduced rates of chlorimuron (4.5 and $\left.6.7 \mathrm{~g} \mathrm{ha}^{-1}\right)$, fomesafen (210 and $315 \mathrm{~g} \mathrm{ha}^{-1}$ ), and lactofen (112 and $\left.168 \mathrm{~g} \mathrm{ha}^{-1}\right)$, promoted injuries in soybean such as leaf chlorosis and reduction of plant height in all treatments. Such injuries were more visible in treatments containing lactofen $(23 \%$ at 28 DAA). Procópio et al. (2007) also observed reductions of height and dry weight in soybean plants shoots when these were treated with glyphosate+imazethapyr at 28 days after soybean emergence.

Observed reductions in plant height may have contributed to slower soil cover by crop canopy (Table 2). In spite of the fact that the mixture glyphosate+bentazon affected plant height at 90 DAA, no significant reduction in the soil cover by crop canopy was observed for all evaluations carried out. Mixtures with cloransulam and flumiclorac-pentyl did not cause any negative effects on soybean growth.

Although negative effects of some mixtures and even isolated glyphosate might have been observed in relation to plant growth (canopy development and plant height), they did not cause plant death in any case, which was evidenced by stand data (data not shown).

Considering both soybean canopy and height, it is evident that crop growth may be affected at some level. Previous work carried out with twenty glyphosate-resistant (GR) soybeans cultivated in Brazil provided evidences that in most cases the nodulation and, therefore, $\mathrm{N}$ fixation can be decreased by the application of glyphosate to GR soybeans (Oliveira Jr. et al., 2008).

\section{Number of pods per plant, hundred grain mass, and yield}

The average values obtained for the number of pods, hundred grain mass, and yield are represented in Table 4 . When the average number of pods per soybean plant for each herbicide treatment was compared to its 
Table 4 - Average number of pods per plant, hundred grain mass (g), and soybean crop yield (kg ha $\left.{ }^{-1}\right)$, CD 214 RR cultivar, submitted to different treatments with glyphosate isolated or in mixture of other herbicides in postemergence. Floraí, PR, 2006/2007

\begin{tabular}{|c|c|c|c|c|c|c|c|}
\hline \multirow{3}{*}{ Herbicide } & \multirow{3}{*}{$\begin{array}{l}\text { Rate } \\
\left(\mathrm{g} \mathrm{ha}^{-1}\right)\end{array}$} & \multirow{2}{*}{\multicolumn{2}{|c|}{$\frac{\mathrm{N}^{\mathrm{o}} \text {. pods (pods per plant) }}{\text { Herbicide }^{1 /}}$}} & \multirow{2}{*}{\multicolumn{2}{|c|}{$\begin{array}{c}\text { Hundred grain mass (g) } \\
\text { Herbicide }^{\underline{1}}\end{array}$}} & \multirow{2}{*}{\multicolumn{2}{|c|}{$\frac{\text { Grain Yield }\left(\mathrm{kg} \mathrm{ha}^{-1}\right)}{\text { Herbicide }^{1 /}}$}} \\
\hline & & & & & & & \\
\hline & & With & Without & With & Without & With & Without \\
\hline Glyphosate+cloransulam-methyl & $960+30.24$ & $53.25 \mathrm{a}$ & $46.75 \mathrm{a}$ & $12.11 \mathrm{a}$ & $12.11 \mathrm{a}$ & $2952.68 \mathrm{a}$ & $2993.03 \mathrm{a}$ \\
\hline Glyphosate+fomesafen & $960+125$ & $37.75 \mathrm{~b}$ & $48.50 \mathrm{a}$ & $12.10 \mathrm{a}$ & $12.35 \mathrm{a}$ & $2849.74 \mathrm{a}$ & $3083.33 \mathrm{a}$ \\
\hline Glyphosate+lactofen & $960+72$ & $46.00 \mathrm{a}$ & $47.25 \mathrm{a}$ & $11.67 \mathrm{~b}$ & $12.30 \mathrm{a}$ & $2672.05 \mathrm{~b}$ & $3057.42 \mathrm{a}$ \\
\hline Glyphosate+chlorimuron-ethyl & $960+12.5$ & $39.75 \mathrm{a}$ & $48.25 \mathrm{a}$ & $12.41 \mathrm{a}$ & $12.27 \mathrm{a}$ & $3082.55 \mathrm{a}$ & $3120.14 \mathrm{a}$ \\
\hline Glyphosate+flumiclorac-pentyl & $960+30$ & $45.00 \mathrm{a}$ & $43.25 \mathrm{a}$ & $12.29 \mathrm{a}$ & $12.20 \mathrm{a}$ & $3041.84 \mathrm{a}$ & $2987.74 \mathrm{a}$ \\
\hline Glyphosate+bentazon & $960+480$ & $37.75 \mathrm{a}$ & $40.25 \mathrm{a}$ & $12.32 \mathrm{a}$ & $12.35 \mathrm{a}$ & $2974.55 \mathrm{a}$ & $3132.18 \mathrm{a}$ \\
\hline Glyphosate+imazethapyr & $960+80$ & $44.50 \mathrm{a}$ & $45.75 \mathrm{a}$ & $12.42 \mathrm{a}$ & $12.32 \mathrm{a}$ & $2945.81 \mathrm{a}$ & $3043.82 \mathrm{a}$ \\
\hline Glyphosate & 720 & $54.75 \mathrm{a}$ & $40.50 \mathrm{~b}$ & $12.15 \mathrm{a}$ & $12.21 \mathrm{a}$ & $2961.66 \mathrm{a}$ & $3020.81 \mathrm{a}$ \\
\hline Glyphosate & 960 & $44.50 \mathrm{a}$ & $48.50 \mathrm{a}$ & $12.57 \mathrm{a}$ & $12.03 \mathrm{~b}$ & $3088.82 \mathrm{a}$ & $2977.01 \mathrm{a}$ \\
\hline Glyphosate & 1,200 & $43.00 \mathrm{a}$ & $40.50 \mathrm{a}$ & $12.34 \mathrm{a}$ & $12.15 \mathrm{a}$ & $3173.36 \mathrm{a}$ & $3040.39 \mathrm{a}$ \\
\hline Glyphosate & 1,440 & $48.00 \mathrm{a}$ & $45.25 \mathrm{a}$ & $12.18 \mathrm{a}$ & $12.38 \mathrm{a}$ & $2927.52 \mathrm{a}$ & $3077.85 \mathrm{a}$ \\
\hline \multicolumn{2}{|l|}{$\mathrm{CV}(\%)$} & \multicolumn{2}{|c|}{15.61} & \multicolumn{2}{|c|}{2.38} & \multicolumn{2}{|c|}{5.70} \\
\hline \multicolumn{2}{|l|}{ L.S.D. (Tukey, $5 \%$ ) } & \multicolumn{2}{|c|}{10.11} & \multicolumn{2}{|c|}{0.42} & \multicolumn{2}{|c|}{247.30} \\
\hline
\end{tabular}

For each variable analyzed, means followed by the same letters in the same line (with $\mathrm{x}$ without herbicide) do not differ from each other by Tukey test at $5 \%$ probability. ${ }^{1 /}$ Represents treatments which received herbicide application (WITH) and their respective two fold checks which did not receive herbicide treatments. +: Herbicides mixtures

respective check with no herbicide, fomesafen in mixture with glyphosate was the only treatment which significantly decreased such yield component variable. However, this factor did not influence significantly the hundred grain mass and yield.

The glyphosate+lactofen treatment promoted significant reduction in the hundred grain mass showing that initial effects of phytotoxicity and leaf area reduction affected the accumulation of photoassimilates and, consequently, grain formation. There were no significant differences for any other treatment when the evaluated variable was hundred grain mass.

When the average yield of treatments was compared with their respective checks, the only treatment that was significantly different in relation to its check was the glyphosate+ lactofen mixture. This treatment can be considered the only one that did not present selectivity to soybean plant once it was inferior to its check in most characteristics studied. Such final effect might be related to the negative effects on soybean growth characterized by slower soil cover by canopy and lower plant height. Serious injuries after application, allied with the effects on growth, might have led plants to an inadequate vegetative development to meet reproductive needs, consequently presenting lower hundred grain weight and yield.

Based on the conditions in which the experiment was carried out, it is possible to conclude that treatments with glyphosate alone or in mixtures with postemergent herbicides applied at single rate, promoted visual effects of phytotoxicity when applied to glyphosate-resistant soybean. Effects such as reductions on plant height, soil cover by canopy development, number of pods per plant, and hundred grain mass can be observed. Nevertheless, effects related to the development of plants are mostly transient and do not persist during the crop cycle. Among evaluated treatments, only glyphosate+ lactofen was not considered selective to the crop, promoting negative effects on most characteristics evaluated and, consequently, reducing grain yield.

\section{LITERATURE CITED}

CORREIA, N. M.; DURIGAN, J. C. Seletividade de diferentes herbicidas à base de glyphosate a soja RR. Planta Daninha, v. 25, n 2, p 375-379, 2007. 
ELLIS, J. M.; GRIFFIN, J. L. Glyphosate and broadleaf herbicide mixtures for soybean (Glycine max). Weed Technol., v. 17, n. 1, p. 21-27, 2003.

ELMORE, R. W. et al. Glyphosate-resistant soybean cultivar response to glyphosate. Agron. J., v. 93, n. 2, p. 404-407, 2001.

FAGLIARI, J. R.; OLIVEIRA JR., R. S.; CONSTANTIN, J. Métodos de avaliação da seletividade de herbicidas para a cultura da cana-de-açúcar (Saccharum spp.). Acta Sci., v. 23, n. 5, p. 1229-1234, 2001

FAUSEY, J. C.; RENNER, K. A. Incorporating CGA-248757 and flumiclorac into annual weed control programs for corn (Zea mays) and soybean (Glycine max). Weed Technol., v. 15, n. 1, p. 148-154, 2001.

GONZINI, L. C.; HART, S. E.; WAX, L. M. Herbicide combinations for weed management in glyphosate-resistant soybean (Glycine max). Weed Technol., v. 13, n. 2, p. $354-360,1999$.

GREY, T. L.; RAYMER, P. Sicklepod (Senna obtusifolia) and red morningglory (Ipomea coccinea) control in glyphosateresistant soybean with narrow rows and postemergence herbicide mixtures. Weed Technol., v. 16, n. 3, p. 669-674, 2002.

JAREMTCHUK, C. C. et al. Efeito de sistemas de manejo sobre a velocidade de dessecação, infestação inicial de plantas daninhas e desenvolvimento e produtividade de soja. Acta Sci. Agron., v. 30, n. 4, p. 449-455, 2008.

LAMEGO, F. P. et al. Tolerância a interferência de plantas competidoras e habilidade de supressão por genótipos de soja - II. Resposta de variáveis de produtividade.

Planta Daninha, v. 22, n. 4, p. 491-498, 2004.

LICH, J. M.; RENNER, K. A.; PENNER, D. Interaction of glyphosate with postemergence soybean (Glycine max) herbicides. Weed Sci., v. 45, n. 1, p. 12-21, 1997.

MESCHEDE, D. K. et al. Período anterior á interferência de plantas daninhas em soja: estudo de caso com baixo estande e testemunhas duplas. Planta Daninha, v. 22, n. 2, p. 239-246, 2004.
NETO, M. E. F. et al. Seletividade de herbicidas pósemergentes aplicados na soja geneticamente modificada. Planta Daninha, v. 27, n. 2, p. 345-352, 2009.

NORRIS, J. L.; SHAW, D. R.; SNIPES, C. E. Weed control from herbicide combinations with three formulations of glyphosate. Weed Technol., v. 15, n. 3, p. 552-558, 2001.

NORSWORTHY, J. K.; BURGOS, N. R.; OLIVER, L. R. Differences in weed tolerance to glyphosate involve different mechanisms. Weed Technol., v. 15, n. 4, p. 725-731, 2001.

NORSWORTHY, J. K.; OLIVER, L. R. Pitted morningglory interference in drill-seeded glyphosate-tolerant soybean. Weed Sci., v. 50, n. 1, p. 26-33, 2002.

NORSWORTHY, J. K. Tolerance of a glyphosate-resistant soybean to late-season glyphosate applications. Weed Technol., v. 18, n. 2, p. 454-457, 2004.

OLIVEIRA JR., R. S. et al. Nodulação e crescimento de variedades de soja RR sob aplicação de glyphosate, fluazifopp-butyl e fomesafen. Planta Daninha, v. 26, n. 3, p. 619-625, 2008.

PROCÓPIO, S. O. et al. Utilização de chlorimuron-ethyl e imazethapyr na cultura da soja Roundup Ready ${ }^{\circledR}$. Planta Daninha, v. 25, n. 2, p. 365-373, 2007.

REDDY, K. N.; ZABLOTOWICZ, R. M. Glyphosateresistant soybean response to various salts of glyphosate and glyphosate accumulation in soybean nodules. Weed Sci., v. 51, n. 4 , p. 496-502, 2003.

SOCIEDADE BRASILEIRA DA CIÊNCIA DAS PLANTAS DANINHAS - SBCPD. Procedimentos para instalação, avaliação e análise de experimentos com herbicidas. Londrina: $1995.42 \mathrm{p}$.

WEED SCIENCE - INTERNATIONAL SURVEY OF HERBICIDE RESISTANT WEEDS. Disponível em: < http:// www.weedscience.org $>$. Acesso em: 20 jun. 2009.

ZOBIOLE, L. H. S. et al. Glyphosate reduces shoot concentrations of mineral nutrients in glyphosate-resistant soybeans. Plant Soil, v. 328, n. 1, p. 57-69, 2010, 2009. 